\title{
Cell wall hydrolases in the seeds of Euphorbia heterophylla L. during germination and early seedling development
}

\author{
Cecilia N. K. Suda ${ }^{1}$, Marcos S. Buckeridge ${ }^{2}$ and Jarbas F. Giorgini ${ }^{3 *}$
}

\begin{abstract}
${ }^{1}$ Departamento de Bioquímica e Imunologia, Faculdade de Medicina de Ribeirão Preto, Universidade de São Paulo, CEP 14049-900, Ribeirão Preto, SP, Brasil; ${ }^{2}$ Seção de Fisiologia e Bioquímica de Plantas, Instituto de Botânica, CP 4005, CEP 01061-970, São Paulo, SP, Brasil; ${ }^{3}$ Departamento de Biologia, Faculdade de Filosofia, Ciências e Letras de Ribeirão Preto, Universidade de São Paulo, CEP 14040901, Ribeirão Preto, SP, Brasil. Corresponding author: jarbas@ffclrp.usp.br
\end{abstract}

Received: 13/07/2003, Accepted: 23/08/2003

Activities of cell wall hydrolases of Euphorbia heterophylla L. (wild poinsettia) endosperm were investigated during pre- and post-emergence periods, defined as the time interval before and after 2.2 days from the start of imbibition, respectively. The activities of endo- $\beta$-mannanase and $\beta$-mannosidase are higher over the pre-emergence when compared to the post-emergence period and they may be involved in the process of germination in E. heterophylla. On the other hand, the activities of $\beta$ galactosidase, $\beta$-glucosidase, $\alpha$-xylosidase, $\beta$-xylosidase and glucanases, which hydrolyse CMC, xyloglucans from Hymenaea courbaril or Copaifera langsdorffii, xylan, Avicel and lichenan, are higher over the post-emergence period. Activity on laminarin occurs over both periods. The activity of xyloglucanases was promoted in the presence of oligosaccharide XXLG. E. heterophylla endosperm surrounds the embryo and their cotyledons, which increases in area after 1 day from the start of imbibition. Rather than the mobilization of cell wall reserves the activity of hydrolases over the post-emergence period may be related to facilitation of cotyledon expansion by lowering endosperm resistance. The fraction of water-soluble polysaccharides extracted from the seed coat is composed of mannose (15.9\%), galactose (20.5\%), and glucose (63.6\%) whereas the fraction from decoated seed is composed of glucose (11.0\%), galactose (36.9\%) and xylose (47.9\%).

Key words: cotyledon expansion, endosperm, endoglucanase, endomannanase, Euphorbiaceae, xylanase.

Hidrolases da parede celular em sementes de Euphorbia heterophylla L. durante a germinação e desenvolvimento inicial da plântula: Foram investigadas atividades de hidrolases da parede celular no endosperma de Euphorbia heterophylla L. (amendoim-bravo) durante os períodos de pré- e de pós-emergência, definidos, respectivamente, antes e após 2,2 dias desde o início da embebição. Atividades de endo- $\beta$-mananase e $\beta$-manosidase são mais elevadas na pré-emergência e podem estar envolvidas no processo de germinação. Por outro lado, atividades de $\beta$-galactosidase, $\beta$-glucosidase, $\alpha$-xilosidase, $\beta$-xilosidase e de glucanases que hidrolisam CMC, xiloglucanos de Hymenaea courbaril ou Copaifera langsdorffii, xilano, Avicel e liquenano são maiores na pós-emergência. Atividade sobre laminarina ocorre em ambos os períodos. A atividade de xiloglucanases foi promovida na presença do oligossacarídeo XXLG. O endosperma de E. heterophylla envolve o embrião e os cotilédones. Estes aumentam em área a partir do 1o dia do início da embebição. As atividades das hidrolases na pós-emergência podem estar mais relacionadas com o decréscimo da resistência endospérmica para a expansão dos cotilédones do que com a mobilização de reservas da parede celular. A fração de polissacarídeos hidrossolúveis extraída do tegumento é composta de manose (15,9\%), galactose $(20,5 \%)$ e glicose $(63,6 \%)$, e do restante da semente de glicose (11,0\%), galactose $(36,9 \%)$ e xilose $(47,9 \%)$.

Palavras-chave: expansão cotiledonar, endosperma, endoglucanase, endomananase, Euphorbiaceae, xilanase.

\section{INTRODUCTION}

In most seeds radicle emergence characterizes the end of germination and the beginning of seedling development. The activity of cell wall hydrolases such as endo- $\beta$-mannanases and $\beta$-1,3-glucanases during the pre-emergence stage may be related to the softening of the tissue in the micropylar region, where the protrusion of the radicle occurs (LeubnerMetzger et al., 1995; Nonogaki and Morohashi, 1996; 
Sánchez and de Miguel, 1997; Nonogaki et al., 2000; de Miguel et al., 2000; Leubner-Metzger and Meins Jr., 2000). The activity of some mannan- and xyloglucan- degrading enzymes following radicle emergence has been related to degradation of cell wall reserve polysaccharides mobilized to supply the seedling with sugars before it becomes autotrophic (Buckeridge et al., 2000b).

Euphorbia heterophylla L. (wild poinsettia), an Euphorbiaceae, is a native plant of tropical and subtropical America (Hutchinson and Dalziel, 1958) and now widely spread. It is an important weed in at least 28 tropical countries and is present in 37 more (Wilson, 1981). In Brazil it has become a major weed, found mainly in soybean fields (Lorenzi, 2000).

The occurrence of storage cell wall polysaccharides in E. heterophylla seeds has not been studied yet. Apart from a report by Zeier et al. (1999) who investigated cell wall composition of the root endodermis of Ricinus communis, there is little information in the literature related to cell wall composition and cell wall hydrolases in Euphorbiaceae. E. heterophylla endosperm contains as major seed reserves lipids and proteins which comprise $59 \%$ and $27 \%$ of seed dry mass, respectively; but starch has not been detected in the endosperm (Suda and Giorgini, 2000). Therefore, this species does not store large amounts of polysaccharides in the seeds and the physiological role of its cell wall hydrolases following emergence is unclear. In a previous report (Suda and Giorgini, 2003), endo-1,4- $\beta$-glucanases from $E$. heterophylla endosperm were isolated and characterized.

In the present work an investigation was carried out of: a) the monosaccharide composition of water-extractable polysaccharide from the endosperm and the seed coat of $E$. heterophylla, and b) the activities of cell wall hydrolases from the endosperm in relation to germination and the process of endosperm weakening that facilitates cotyledon expansion inside the endosperm.

\section{MATERIAL AND METHODS}

Plant material: Mature fruits of Euphorbia heterophylla L. were collected from native plants and dried at $30{ }^{\circ} \mathrm{C}$ until dehiscence; seeds were stored in air-tight flasks at $5{ }^{\circ} \mathrm{C}$. At this temperature seeds remain viable for several months (Bannon et al., 1978; Suda and Pereira, 1997).

Germination: Seeds were germinated in Petri dishes on two sheets of filter paper moistened with distilled water. The dishes were kept at $30{ }^{\circ} \mathrm{C}$ in the dark. For enzyme extraction, mate- rial was sampled from this population of seeds. For germination tests, four $9 \mathrm{~cm}$ Petri dishes were used, each containing 50 seeds.

Average germination time: The average germination time \pm confidence interval $(95 \%)$ was calculated according to Labouriau and Osborn (1984).

Extraction of cell wall hydrolases: At various time intervals after imbibition, the seeds or seedlings were harvested and their seed coats manually removed. Decoated seeds were dissected and the embryo (cotyledon plus embryo-axis) was separated from the endosperm. One hundred and fifty isolated endosperms were homogenized for $15 \mathrm{sec}$ in a Polytron-type homogenizer with $15 \mathrm{~mL}$ of 0.05 mol. $\mathrm{L}^{-1}$ sodium acetate buffer ( $\mathrm{pH}$ 5.0), containing 0.4 mol. $\mathrm{L}^{-1} \mathrm{NaCl}$ and $0.02 \%$ $\mathrm{NaN}_{3}$. The homogenate was centrifuged at $10,000 g_{\mathrm{n}}$ for 10 min. The supernatant was collected and stored at $-15^{\circ} \mathrm{C}$ prior to use. The enzymes extractions were carried out at $4{ }^{\circ} \mathrm{C}$.

Assay of nitrophenylglycosidases: The reaction mixture contained $15 \mu \mathrm{L}$ of enzyme extract, $15 \mu \mathrm{L}$ of $0.1 \mathrm{~mol}^{-\mathrm{L}^{-1}}$ sodium acetate buffer ( $\mathrm{pH} 5.0$ ), and $15 \mu \mathrm{L}$ of $0.05 \mathrm{~mol}^{\mathrm{L}} \mathrm{L}^{-1}$ (in $\mathrm{H}_{2} \mathrm{O}$ ) of the following $p$-nitrophenyl ( $p$ NP) glycosides (Sigma): $p \mathrm{NP}-\alpha$-D-galactopyranoside or $p \mathrm{NP}-\beta$-D-galactopyranoside for $\alpha$ - and $\beta$-galactosidases, respectively; $p$ NP- $\beta$-Dglucopyranoside for $\beta$-glucosidase; and $p$ NP- $\beta$-Dmannopiranoside for $\beta$-mannosidase. Thirty $\mu \mathrm{L}$ of $p$ nitrophenyl- $\beta$-D-xylopyranoside $\left(7 \mathrm{mmol} . \mathrm{L}^{-1}\right.$ in Mcllvane buffer, $\mathrm{pH}$ 5.0) were added to $15 \mu \mathrm{L}$ of enzyme extract for $\beta$ xylosidase activity. The reaction mixture was incubated at 35 ${ }^{\circ} \mathrm{C}$ during $20 \mathrm{~min}$ for $\beta$-galactosidase and $\beta$-glucosidase activities, and $60 \mathrm{~min}$ for the other enzymes. The reaction was stopped by the addition of $1.5 \mathrm{~mL}$ of 0.05 mol.L $\mathrm{L}^{-1} \mathrm{Na}_{2} \mathrm{CO}_{3}$. The $p$-nitrophenol released was determined by the absorbance at $405 \mathrm{~nm}$ and the enzyme activities calculated using a molar extintion of 18,400 for $p$-nitrophenol in 0.05 mol.L-1 $\mathrm{Na}_{2} \mathrm{CO}_{3}$ (Alcântara et al., 1999). Controls were prepared by adding 1.5 $\mathrm{mL}$ of 0.05 mol. $\mathrm{L}^{-1} \mathrm{Na}_{2} \mathrm{CO}_{3}$ to the reaction mixture prior to incubation (time 0 ). Control values were subtracted from all sample values. Enzyme activity was expressed as Katal (Kat).

Assay of endo- $\beta$-mannanase activities: The reaction mixture contained $100 \mu \mathrm{L}$ of enzyme extract and $200 \mu \mathrm{L}$ of substrate solution (either $0.8 \%$ guar gum or $0.8 \%$ locust bean galactomannan, both from Sigma, in 0.05 mol.L $\mathrm{L}^{-1}$ sodium acetate buffer, $\mathrm{pH} 5.0$, containing $0.02 \% \mathrm{NaN}_{3}$ ). The changes 
in drainage time of the mixture through a calibrated upper portion of a $0.1 \mathrm{~mL}$ pipette at $30^{\circ} \mathrm{C}$ were used as a measure of viscosity. Drainage times were converted to relative units of enzymic activity (Almin et al., 1967) using -1.68 as the value of the empirical substrate specific constant (Eriksson and Winnel, 1968). In preliminary experiments the linear relationships "enzyme activity vs. enzyme concentration" and "intrinsic viscosity $\left(\mathrm{N}^{-1.68}\right)$ vs. incubation time" were checked.

Assay of endoglucanase by the viscometric method: The reaction mixture contained $1.5 \mathrm{~mL}$ of the enzyme extract and $13.5 \mathrm{~mL}$ of $0.3 \%$ carboxymethylcellulose (CMC type 7H3SF, Hercules Incorporated) in 0.05 mol. $\mathrm{L}^{-1}$ sodium acetate buffer, pH 5.0, containing 0.1 mol. $\mathrm{L}^{-1} \mathrm{NaCl}$ and $0.02 \% \mathrm{NaN}_{3}$. Viscosity changes were measured using a glass Ostwald viscometer maintained at $30{ }^{\circ} \mathrm{C}$ by a circulating water-bath. Initial flow time of the assay mixture was about $130 \mathrm{~s}$; flow time of distilled water was $29 \mathrm{sec}$. These times were converted to relative units of endoglucanase activity using -3.66 as the value of the empirical substrate specific constant (Almin et al., 1967; Durbin and Lewis, 1988).

Assay of glucanases and xylanases: The reaction mixture contained $100 \mu \mathrm{L}$ of enzyme extract and $500 \mu \mathrm{L}$ of substrate (1.2\% CMC type 7H3SF (Hercules Incorporated), $1.2 \%$ xylan from oat spelt (Sigma), $0.25 \%$ laminarin from Laminaria digitata (Sigma), $0.5 \%$ Avicel (Merck) or $0.25 \%$ lichenan from Cetraria islandica (Sigma)) in 0.05 mol. $\mathrm{L}^{-1}$ sodium acetate buffer, $\mathrm{pH} 5.0$, containing 0.1 mol. $\mathrm{L}^{-1} \mathrm{NaCl}$ and $0.02 \% \mathrm{NaN}_{3}$. The Avicel was dissolved in the above buffer without $\mathrm{NaCl}$. The mixture was incubated at $30{ }^{\circ} \mathrm{C}$ during $60 \mathrm{~min}$ and the reducing power produced was determined by the Nelson-Somogyi method (Somogyi, 1952).

Assays of overall xyloglucan-degrading activity: The activities were determined according to Sulová et al. (1995). For overall xyloglucan-degrading activity the reaction mixture contained $100 \mu \mathrm{L}$ of enzyme extract, $100 \mu \mathrm{L}$ of substrate (either $0.04 \%$ xyloglucan of Hymenaea courbaril or Copaifera langsdorffii in 0.05 mol. $\mathrm{L}^{-1}$ sodium acetate buffer containing $\left.0.02 \% \mathrm{NaN}_{3}\right)$ and $15 \mu \mathrm{L}$ of oligosaccharide XXLG (10 kg. $\mathrm{mL}^{-1}$ in water) or $15 \mu \mathrm{L}$ of water (without XXLG). The blank sample contained no xyloglucan and the control sample contained no enzyme. The mixtures were incubated at $30^{\circ} \mathrm{C}$ for $30 \mathrm{~min}$ and the reaction stopped by addition of $0.1 \mathrm{~mL}$ of $1.0 \mathrm{~mol} . \mathrm{L}^{-1} \mathrm{HCl}$. To each sample, $1.0 \mathrm{~mL}$ of $20 \% \mathrm{Na}_{2} \mathrm{SO}_{4}$ and $0.2 \mathrm{~mL}$ of iodine solution $\left(0.5 \% \mathrm{I}_{2}+1.0 \% \mathrm{KI}\right)$ were added and the tubes were allowed to stand for $1 \mathrm{~h}$ in the dark. The optical density was measured at $620 \mathrm{~nm}$ against the blank. The enzyme activity was expressed in arbitrary units and corresponds to the percentage of substrate (xyloglucan) degraded to molecular species with $\mathrm{Mr}<10 \mathrm{kDa}$ during the assay.

The decrease in xyloglucan-iodine complex was calculated subtracting absorbance values of assays without XXLG from values of assays containing XXLG.

Hymenaea courbaril xyloglucan and purified XXLG were kindly provided by Dr. Carem G. Vargas-Rechia (Faculdade de Ciências Farmacêuticas de Ribeirão Preto, Universidade de São Paulo). Copaifera langsdorffii xyloglucan was prepared according to Buckeridge and Dietrich (1990) and Alcântara et al. (1999).

Assay of $\alpha$-xylosidase: The activities were determined by assaying the free pentose released according to Roe and Rice (1948) as modified by Edwards et al. (1985). The assay mixture consisted of $20 \mu \mathrm{L}$ enzyme extract and $50 \mu \mathrm{L}$ substrate (either $0.2 \%$ xyloglucan from Hymenaea courbaril or $0.2 \%$ xyloglucan from Copaifera langsdorffii in $0.1 \mathrm{~mol}^{\mathrm{L}} \mathrm{L}^{-1}$ sodium acetate buffer, $\mathrm{pH}$ 5.0, containing $0.02 \% \mathrm{NaN}_{3}$ ). The mixture was incubated at $30{ }^{\circ} \mathrm{C}$ for $24 \mathrm{~h}$ and free pentose determined using xylose as standard.

Isolation of the polysaccharides: The seed coat of quiescent seeds was removed and polysaccharides were extracted from both seed coats and decoated seeds. Decoated seeds $(6.0 \times$ $10^{-3} \mathrm{~kg}$ ) were homogenized for $30 \mathrm{sec}$ in a Polytron-type homogenizer in chloroform-methanol $(2: 1, \mathrm{v} / \mathrm{v})$ to remove lipids. Raw extract volume was adjusted to $60 \mathrm{~mL}$ with chloroform-methanol $(2: 1, \mathrm{v} / \mathrm{v})$ and stirred. Following centrifugation at 2,000 $g_{\mathrm{n}}$ for $10 \mathrm{~min}$ the supernatant was discarded and the pellet re-extracted with $60 \mathrm{~mL}$ chloroform-methanol. After 3 extractions followed by centrifugation the pellet was dried at $30{ }^{\circ} \mathrm{C}$ for $48 \mathrm{~h}$.

Polysaccharides extraction was performed according to Buckeridge and Dietrich (1990). Seed coats $\left(2.5 \times 10^{-3} \mathrm{~kg}\right)$ or defatted seed powder $\left(2.7 \times 10^{-3} \mathrm{~kg}\right)$ as obtained above were stirred in 250 or $270 \mathrm{~mL}$ distilled water $\left(80^{\circ} \mathrm{C}\right)$, respectively, for $8 \mathrm{~h}$. The resulting extract was filtered through nylon cloth to remove remaining insoluble residues. Polysaccharides were precipitated from the extract with 3 volumes of ethanol. The precipitate was left overnight at $5{ }^{\circ} \mathrm{C}$, collected by filtration through nylon cloth and dried at $60{ }^{\circ} \mathrm{C}$. The dried material was resuspended in hot water and centrifuged $\left(13,000 g_{\mathrm{n}}, 15 \mathrm{~min}\right)$. The supernatant was collected and freeze dried. 
High-performance anion-exchange chromatography with pulsed amperometric detection (HPAEC-PAD): Acid hydrolysis of the polysaccharides was performed by a pre-incubation of $10 \mathrm{mg}$ of the freeze-dried material in $0.1 \mathrm{~mL}$ of $72 \%$ $\mathrm{H}_{2} \mathrm{SO}_{4}$ at $30{ }^{\circ} \mathrm{C}$ for $30 \mathrm{~min}$ followed by dilution to a concentration of $3 \% \mathrm{H}_{2} \mathrm{SO}_{4}$ with distilled water and hydrolysis in an autoclave for $1 \mathrm{~h}$ at $120^{\circ} \mathrm{C}$ (Saeman et al., 1954). After hydrolysis, the solution was neutralized with $\mathrm{NaOH}$ (Dionex). The resulting monosaccharides were analysed by HPAECPAD (Dionex PD40 Diode Array Detector) on a CarboPac PA-1 columm eluted by pure water (flow rate $1.0 \mathrm{~mL} \cdot \mathrm{min}^{-1}$ ) and post-columm detection with $0.50 \mathrm{~mol} \cdot \mathrm{L}^{-1} \mathrm{NaOH}$. The relative proportions of monosaccharides were corrected according to detector sensitivity to each monosaccharide, calculated by using equimolar standards.

Assay of protein: Protein content was determined by the method of Bradford (1976), using bovine serum albumin as standard.

Determination of cotyledon area: At various time intervals after the start of imbibition seeds were collected, cotyledons excised and their maximum length (a) and width (b) measured. Since the shape of E. heterophylla cotyledons is approximately elliptic, the area was estimated using the equation for an ellipse: Area $=\pi .(a / 2) .(b / 2)$

\section{RESULTS}

When seeds of E. heterophylla are soaked in water, a transparent, gel-like coating of mucilage is extruded and envelops the seeds. During polysaccharide extraction only a part of the mucilage could be dissolved in hot water $\left(80^{\circ} \mathrm{C}\right)$ indicating that it may be composed of water-soluble and waterinsoluble substances.

As shown in the table 1, water-extractable polysaccharides from E. heterophylla seed coat are composed of glucose, galactose and mannose whereas from decoated seeds they are composed of xylose, galactose, glucose and arabinose. Mannose was not detected in decoated seeds of $E$. heterophylla.

The average germination time of E. heterophylla seed was $2.2 \pm 0.7$ days. In the present work, pre- and post-emergence periods were respectively defined as the time interval before and after 2.2 days from the start of imbibition.

As shown in figure 1, cotyledon area increased 4.4 fold between 0 and 2 days (pre-emergence), and 1.7 fold between 2 and 4 days from the start of imbibition (post-emergence).
Table 1. Composition of monosaccharides ( $\%$ of total ) obtained by acidic hydrolysis of polysaccharides extracted from the seed coat and decoated seeds of E. heterophylla.

\begin{tabular}{lcc}
\hline Monosaccharides & Seed Coat & Decoated Seed \\
\hline Fucose & 0.0 & 0.0 \\
Rhamnose & 0.0 & 0.0 \\
Arabinose & 0.0 & 4.2 \\
Galactose & 20.5 & 36.9 \\
Glucose & 63.6 & 11.0 \\
Xylose & 0.0 & 47.9 \\
Mannose & 15.9 & 0.0 \\
\hline
\end{tabular}

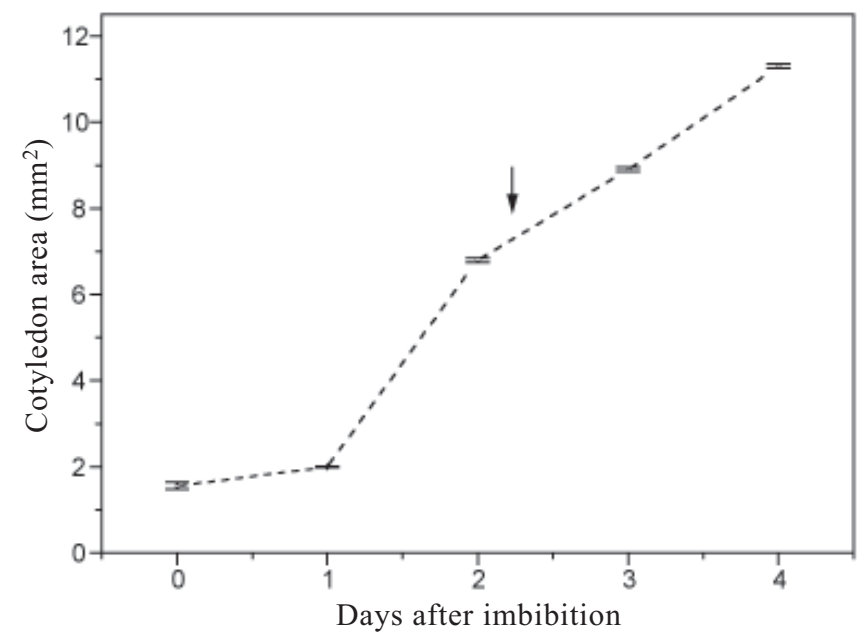

Figure 1. Variation of cotyledon area during germination of $E$. heterophylla. Values are means \pm standard errors of 15 measurements. The arrow indicates average germination time.

As shown in figure $2 \mathrm{~A}$, endo- $\beta$-mannanase ativity was already present in quiescent seeds (time 0 ) and its level decreased during pre-emergence, remaining low during the postemergence period. The activity on locust bean galactomannan was higher than the activity on guar galactomannan.

$\beta$-mannosidase activity was also present in the quiescent seed, however its level decreased approximately $78 \%$ up to $24 \mathrm{~h}$ and remained constant thereafter (figure 2B). Unlike endo- $\beta$-mannanase and $\beta$-mannosidade, the levels of $\alpha$-galactosidase increased during the post-emergence period (figure $2 \mathrm{~B}$ ).

As shown in figure $2 \mathrm{C}$, there was $\beta$-1,3-glucanase activity on laminarin during both pre-emergence and post-emergence periods. The xylanase and $\beta$-xylosidase activities in $E$. heterophylla endosperm remained essentially constant during pre-emergence and increased during the post-emergence period (figure 2D). 

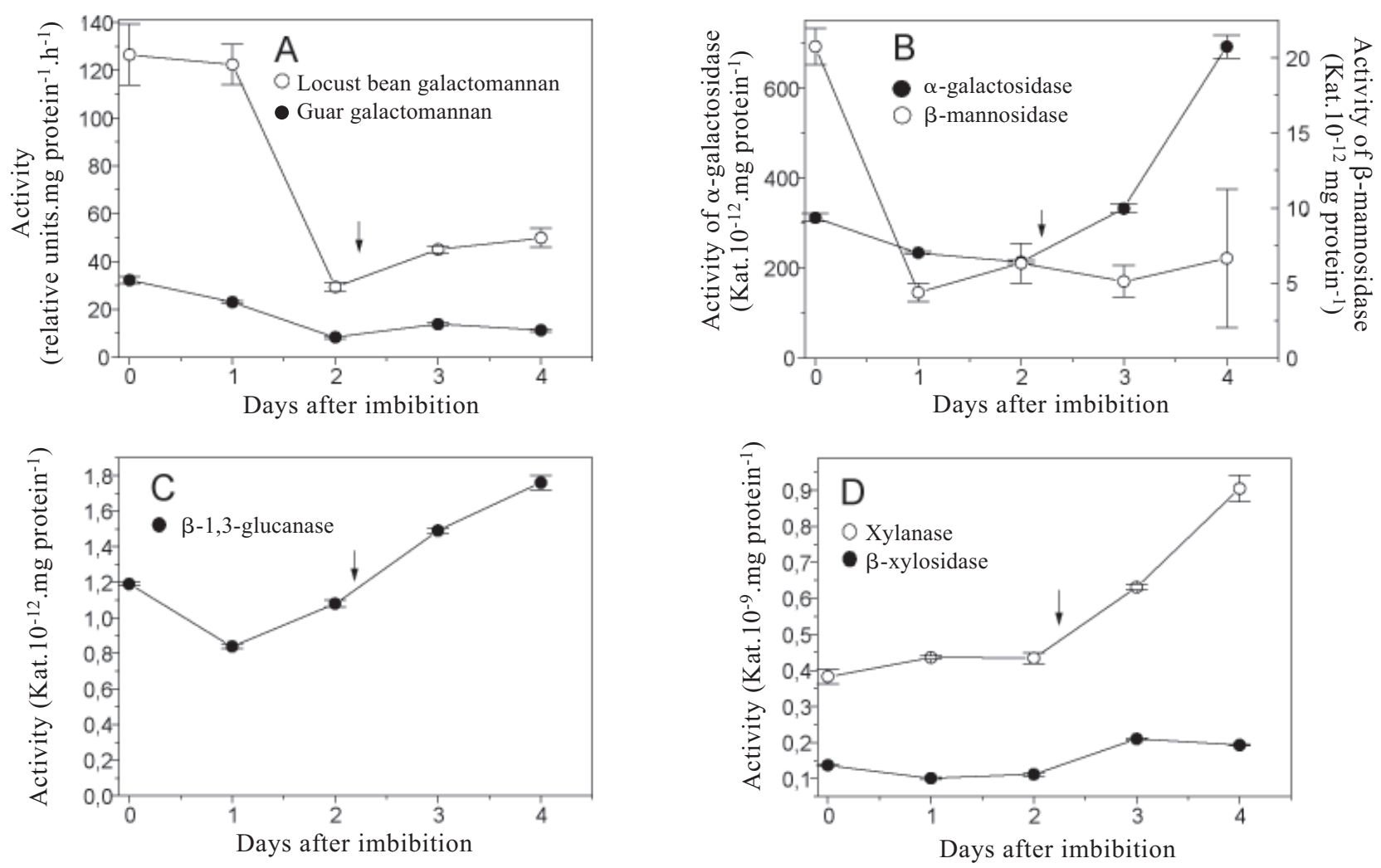

Figure 2. Time course of galactomannan-, laminarin- and xylan-degrading enzymes from E. heterophylla endosperm. (A) Activity of endo- $\beta$-mannanase on locust bean or guar galactomannans. (B) Activities of $\alpha$-galactosidase and $\beta$-mannosidase. (C) Activity of $\beta$-1,3-glucanase on laminarin. (D) Activities of xylanase and $\beta$-xylosidase. Vertical bars represent standard errors of three experiments. The arrow indicates average germination time.

The xyloglucan-degrading activity during pre-emergence was slightly higher in the presence of xyloglucan from $H$. courbaril than in the presence of the xyloglucan from $C$. langsdorffii (figure 3A). The activity was low during preemergence increasing after radicle emergence in both assays: with XXLG (not shown) or without XXLG (figure 3A). However, the activity was always higher in the presence of XXLG than without it, indicating that XXLG promotes xyloglucanase activity in E. heterophylla. The difference between these two assays is showed in figure 3B. In the mixture containing xyloglucan, XXLG and extract from quiescent seeds (time 0 ), the amount of xyloglucan-iodine complex decreased 52.8 $\%$ or $27.3 \%$ in relation to a corresponding mixture without XXLG (figure 3B). The color intensity of the mixture decreased since xyloglucan was cleaved and the colorization of fragments generated below $10 \mathrm{kDa}$ does not occur (Sulová et al., 1995). Nevertheless, the difference between the two assays decreased during pre-emergence becoming undetectable during post-emergence (figure $3 \mathrm{~B}$ ). $\beta$-galactosidase activity of $E$. heterophylla seeds slightly decreased during $24 \mathrm{~h}$ after seed imbibition, increasing continuously thereafter (figure
3C). $\beta$-glucosidase activities were relatively constant during pre-emergence increasing slightly during the post-emergence period (figure 3C).

The activity of $\alpha$-xylosidase on both $H$. courbaril and $C$. langsdorffii xyloglucans increased from the $1^{\text {st }}$ day after imbibition (figure 3D). However, while the activity on $H$. courbaril xyloglucan increased continuously up to the $3^{\text {rd }}$ day decreasing thereafter, the activity on C. langsdorffii xyloglucan remained high during the post-emergence period. A minor fraction of $H$. courbaril xyloglucan is composed of arabinose (Tiné et al., 2000), thus the activity of $E$. heterophylla $\alpha$-xylosidase activity on $H$. courbaril xyloglucan may be the sum of arabinosidase plus $\alpha$-xylosidase activities because the method assayed released free pentose.

The hydrolytic activities on CMC (figure 3E), Avicel or lichenan (figure 3F) were very low or not detected during pre-emergence and increased only in the post-emergence period. The activity profile on CMC determined by viscometry was similar to that of activity determined by reducing power production (figure $3 \mathrm{E}$ ). 

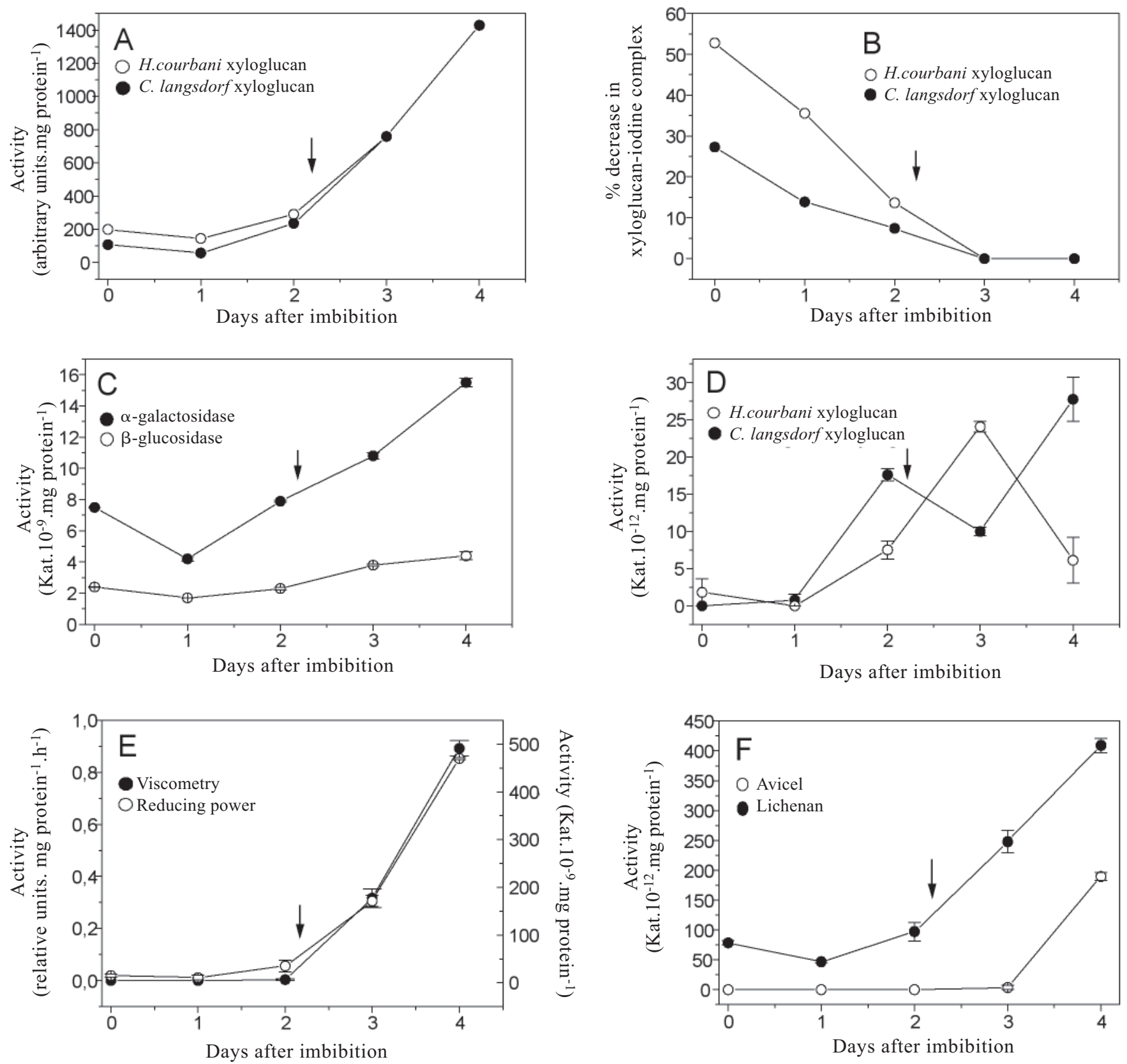

Figure 3. Time course of endoglucanases, $\beta$-galactosidase and $\beta$-glucosidase activities from E. heterophylla endosperm. (A) Overall xyloglucan-degrading activity. (B) Decrease in amount of xyloglucan-iodine complex in the presence of XXLG. (C) Activities of $\beta$-galactosidase and $\beta$-glucosidase. (D) Activity of $\alpha$-xylosidase on either xyloglucans. (E) Activity of endoglucanase on $\mathrm{CMC}$ determined by viscometry (left scale) and by reducing power production (right scale). (F) Activities of endoglucanase on Avicel and lichenan. Xyloglucans from H. courbaril and C. langsdorffii were used as substrates in A, B and D. Vertical bars represent standard errors of three experiments. The arrow indicates average germination time.

\section{DISCUSSION}

The occurrence of galactose and mannose suggests the presence of galactomannan in the seed coat. Moreover, the high level of glucose also suggests the presence of a glucan in E. heterophylla seed mucilage. Glucans have been detected in seed mucilages, such as from Sinapis alba (mustard) which contains a water-soluble heterogeneous polysaccharide of a 1,4-linked $\beta$-D-glucan (similar to cellulose but more branched) and a pectic material (Balke and Diosady, 2000). Seeds of Cydonia oblonga (quince) release a water-extract- 
able mucilage containing cellulose microfibrils tightly associated with a highly acidic glucuronoxylan (Reis et al., 1991). Activities of endo- $\beta$-mannanase, $\alpha$-galactosidase and $\beta$ mannosidase have been associated with galactomannan mobilization (Buckeridge et al., 2000a). However, water-soluble galactomannans probably do not occur in E. heterophylla endosperm because mannose was not detected in the endosperm of $E$. heterophylla. It is possible that endo- $\beta$ mannanase activity in E. heterophylla was related to degradation of structural mannan of the cell wall, not extractable by hot water. Since the activity of E. heterophylla endo- $\beta$ mannanase on locust bean galactomannan was higher than the activity on guar galactomannan, it is possible that the enzyme preferably degrades galactomannans with fewer galactosyl branch-points such as pure mannans, which are insoluble in water (Buckeridge et al., 2000a,b). The mannose:galactose ratio of galactomannans from locust bean and guar are approximately 3.5 and 1.5 , respectively (Daas et al., 2000). The activity of E. heterophylla endo- $\beta$ mannanase was high during pre-emergence suggesting a possible role in endosperm weakening in order to allow radicle emergence.

The substrate of $\alpha$-galactosidase in E. heterophylla endosperm is uncertain. The $\alpha$-galactosidase is also involved in raffinose degradation (McCleary and Matheson, 1974; Buckeridge and Dietrich, 1996), however this oligosaccharide was not detected in E. heterophylla endosperm (Suda and Giorgini, 2000). Other Euphorbiaceae such as Ricinus communis (castor bean) or Hevea brasiliensis (rubber) do not have raffinose in their seeds either (Amuti and Pollard, 1977; Achinewhu, 1986).

The activity of $\beta$-1,3-glucanase from $E$. heterophylla endosperm during pre-emergence may be related to hydrolysis of $\beta-1,3$-glucan to facilitate radicle protrusion. The activity during post-emergence may be related to completion of endosperm cell wall degradation.

The presence of xylan-degrading enzymes and the high level of xylose in the water-soluble polysaccharide from endosperm strongly suggest the occurrence of xylan compounds as cell wall reserve, probably mobilized after seed germination. To the authors' knowledge, only one study has attempted to measure xylanase activity of dicotyledonous seeds during germination (Wankhede et al., 1977). In contrast to $E$. heterophylla xylanases, in Arachis hypogea (groundnut) the activity of pentosanase (xylanase) increases prior to radicle emergence (Wankhede et al., 1977).
Endo- $\beta$-1,4-glucanase or xyloglucan endo-transglycosylase (XET), $\beta$-galactosidase, $\beta$-glucosidase and $\alpha$ xylosidase are considered the main enzymes associated with the mobilization of xyloglucans (Edwards et al., 1985; Crombie et al., 1998; Tiné et al., 2000). In E. heterophylla seeds the overall xyloglucan-degrading activity, imputed to endo- $\beta-1,4$-glucanase activity, increased during the postemergence period together with $\beta$-galactosidase and $\beta$-glucosidase activities. The increase in $\alpha$-xylosidase activity started before these other enzymes but the activity was present during the post-emergence period. These results and the occurrence of xylose, galactose and glucose in water-extractable polysaccharide from $E$. heterophylla endosperm strongly suggest xyloglucan as the cell wall component degraded, mainly during post-emergence in this species.

We have evidence for the existence of endo-1,4- $\beta$ glucanases which degrade CMC and xyloglucans in $E$. heterophylla endosperm (Suda and Giorgini, 2003), since profiles of CMC- and xyloglucan-degrading activities were similar over the experimental period. Besides xyloglucan another potential target for E. heterophylla endoglucanases are accessible sites in the peripheral and integral noncrystalline regions of cellulose microfibril as proposed for avocado Cx cellulase (O'Donoghue et al., 1994). It is also possible that E. heterophylla endoglucanases depolymerize xyloglucans and noncrystalline regions of cellulose for further attack of Avicelase on crystalline cellulose. In fact, the increase of Avicelase activity occurred after the increase of other endoglucanases in E. heterophylla endosperm. It is noteworthy that few plant cellulases are able to degrade crystalline cellulose (O’Donoghue et al., 1994; Rose and Bennet, 1999).

E. heterophylla endosperm contains high amounts of lipids and proteins which together comprise about $86 \%$ of seed dry mass (Suda and Giorgini, 2000) and its degradation is paralleled by cotyledon expansion. E. heterophylla endosperm surrounds the embryo and their cotyledons, which expand continuously inside the seed during germination and early seedling development. Rather than mobilization of cell wall reserves, the activity of hydrolases during post-emergence in E. heterophylla probably facilitates cotyledon expansion by degrading endosperm cell walls and lowering endosperm resistance and at the same time facilitates the diffusion of degradation products into cotyledons.

Xyloglucanases have been investigated only in the seeds that store xyloglucan in the cotyledons (Edwards et al., 1985; Sulová et al., 1995; Tiné et al., 2000; Steele et al., 2001) but little information is available on this enzyme in endospermic seeds. 
Acknowledgments: We thank Ms. Liliana Martim and Mr. Clovis O. Silva for assistance with polysaccharide isolation and analysis of monosaccarides by HPAEC-PAD and Mr. Jaime L. Zeotti for general technical assistance. We are grateful for helpful advice and suggestions given by Dr. Rita C.L.F. Ribeiro. This work was supported by grants 92/3176-4 and 96/8069-2 from FAPESP to J.F.G. C.N.K.S. acknowledges the receipt of a doctoral fellowship from CAPES.

\section{REFERENCES}

Achinewhu SC (1986) Unconventional sources of food: chemical composition of rubber seed (Hevea brasiliensis). Food Chem. 21:17-25.

Alcântara PHN, Dietrich SMC, Buckeridge MS (1999) Xyloglucan mobilisation and purification of a (XLLG/ XLXG) specific $\beta$-galactosidase from cotyledons of Copaifera langsdorffii. Plant Physiol. Biochem. 37:653-663.

Almin KE, Eriksson K-E, Jansson C (1967) Enzymic degradation of polymers. 2. Viscometric determination of cellulase activity in absolute terms. Biochim. Biophys. Acta 139:248-253.

Amuti KS, Pollard CJ (1977) Soluble carbohydrates of dry and developing seeds. Phytochemistry 16:529-532.

Balke DT, Diosady LL (2000) Rapid aqueous extraction of mucilage from whole white mustard seed. Food Res. Int. 33:347-356.

Bannon JS, Baker JB, Rogers RL (1978) Germination of wild poinsettia (Euphorbia heterophylla). Weed Sci. 26:221-225.

Bradford MM (1976) A rapid and sensitive method for the quantitation of microgram quantities of protein utilizing the principle of protein-dye binding. Anal. Biochem. 72:248-254.

Buckeridge MS, Dietrich SMC (1990) Galactomannans from Brazilian legume seeds. Braz. J. Bot. 13:109-112.

Buckeridge MS, Dietrich SMC (1996) Mobilisation of the raffinose family oligosaccharides and galactomannan in germinating seeds of Sesbania marginata Benth. (Leguminosae-Faboideae). Plant Sci. 117:33-43.

Buckeridge MS, Dietrich SMC, Lima DU (2000a) Galactomannans as the reserve carbohydrate in legume seeds. In: Gupta AK, Kaur N (eds), Carbohydrate Reserves in Plants - Synthesis and Regulation, pp. 283-316. Elsevier Science BV.

Buckeridge MS, Pessoa dos Santos H, Tiné MAS (2000b) Mobilisation of storage cell wall polysaccharides in seeds. Plant Physiol. Biochem. 38: 141-156.

Crombie HJ, Chengappa S, Hellyer A, Reid JSG (1998) A xyloglucan oligosaccharide-active, transglycosylating $\beta$-Dglucosidase from the cotyledons of nasturtium (Tropaeolum majus L.) seedlings - purification, properties and characterization of a cDNA clone. Plant. J. 15:27-38.

Daas PJH, Schols HA, de Jongh HHJ (2000) On the galactosyl distribution of commercial galactomannans. Carbohydr. Res. 329:609-619. de Miguel L, Burgin MJ, Casal JJ, Sánchez RA (2000) Antagonistic action of low-fluence and hight-irradiance modes of response of phytochrome on germination and $\beta$-mannanase activity in Datura ferox seeds. J. Exp. Bot. 51: 1127-1133.

Durbin ML, Lewis LN (1988) Cellulases in Phaseolus vulgaris. In: Wood WA, Kellogg ST (eds), Methods in Enzymology, Vol. 160, pp. 342-351. Academic Press, New York.

Edwards M, Dea ICM, Bulpin PV, Reid JSG (1985) Xyloglucan (amyloid) mobilisation in the cotyledons of Tropaeolum majus L. seeds following germination. Planta 163: 133-140.

Eriksson K-E, Winell M (1968) Purification and characterisation of a fungal $\beta$-mannanase. Acta Chem. Scand. 22:1924-1934.

Hutchinson J, Dalziel JM (1958) Flora of West Tropical Africa, Vol. I (ii). $2^{\text {nd }}$ edn revised by Keay RWJ (1973), pp. 297-828. Crown Agents for Overseas Governments and Administrations, London.

Labouriau LG, Osborn JH (1984) Temperature dependence of the germination of tomato seeds. J. Therm. Biol. 9:285-294.

Leubner-Metzger G, Meins Jr F (2000) Sense transformation reveals a novel role for class I $\beta$-1,3-glucanase in tobacco seed germination. Plant J. 23:215-221.

Leubner-Metzger G, Fründt C, Vögeli-Lange R, Meins Jr F (1995) Class I $\beta$-1,3-glucanases in the endosperm of tobacco during germination. Plant Physiol. 109: 751-759.

Lorenzi H (2000) Plantas Daninhas do Brasil; Terrestres, Aquáticas, Parasitas e Tóxicas. $3^{\text {rd }}$ edn. Instituto Plantarum, Nova Odessa.

McCleary BV, Matheson NK (1974) $\alpha$-D-galactosidase activity and galactomannan and galactosylsucrose oligosaccharide depletion in germinating legume seeds. Phytochemistry 13:1747-1757.

Nonogaki H, Morohashi Y (1996) An endo- $\beta$-mannanase develops exclusively in the micropylar endosperm of tomato seeds prior to radicle emergence. Plant Physiol. 110:555-559.

Nonogaki H, Gee OH, Bradford KJ (2000) A germinationspecific endo- $\beta$-mannanase gene is expressed in the micropylar endosperm cap of tomato seeds. Plant Physiol. 123:1235-1245.

O’Donoghue EM, Huber DJ, Timpa JD, Erdos GW, Brecht JK (1994) Influence of avocado (Persea americana) Cxcellulase on the structural features of avocado cellulose. Planta 194:573-584.

Reis D, Vian B, Chanzy H, Roland J-C (1991) Liquid crystal-type assembly of native cellulose-glucuronoxylans extracted from plant cell wall. Biol. Cell 73: 173-178.

Roe JH, Rice EW (1948) A photometric method for the determination of free pentoses in animal tissues. J. Biol. Chem. 173:507-512.

Rose JKC, Bennett AB (1999) Cooperative disassembly of the cellulose-xyloglucan network of plant cell walls: par- 
allels between cell expansion and fruit ripening. Trends Plant Sci. 4:176-183.

Saeman JF, Moore WE, Mitchell RL, Millet MA (1954) Techniques for the determination of pulp constituents by quantitative paper chromatography. Tappi 37: 336-343.

Sánchez RA, de Miguel L (1997) Phytochrome promotion of mannan-degrading enzyme activities in the micropylar endosperm of Datura ferox seeds requires the presence of the embryo and gibberellin synthesis. Seed Sci. Res. 7:27-33.

Somogyi M (1952) Notes on sugar determination. J. Biol. Chem. 195:19-23.

Steele NM, Sulová Z, Campbell P, Farkaš V, Fry SC (2001) Ten isoenzymes of xyloglucan endotransglycosylase from plant cell walls select and cleave the donor substrate stochastically. Biochem. J. 355:671-679.

Suda CNK, Giorgini JF (2000) Seed reserve composition and mobilization during germination and initial seedling development of Euphorbia heterophylla. Rev. Bras. Fisiol. Veg. 12:226-244.

Suda CNK, Pereira MFDA (1997) Sensibilidade à luz de sementes de Euphorbia heterophylla L. durante a germinação. Rev. Bras. Fisiol. Veg. 9:61-66.
Suda CNK, Giorgini JF (2003) Multiple forms of endo-1,4$\beta$-glucanases in the endosperm of Euphorbia heterophylla L. J. Exp. Bot. 54:2045-2052.

Sulová Z, Lednická M, Farkaš V (1995) A colorimetric assay for xyloglucan-endotransglycosylase from germinating seeds. Anal. Biochem. 229:80-85.

Tiné MAS, Cortelazzo AL, Buckeridge MS (2000) Xyloglucan mobilisation in cotyledons of developing plantlets of Hymenaea courbaril L. (LeguminosaeCaesalpinoideae). Plant Sci. 154:117-126.

Wankhede DB, Saroja R, Rao MR (1977) Changes in carbohydrates and the activity of $\alpha$-galactosidase, pentosanase and lipase during germination of groundnuts (Arachis hipogea). J. Sci. Food Agric. 28:167-172.

Wilson AK (1981) Euphorbia heterophylla: a review of distribution, importance and control. Trop Pest Manage. 27:32-38.

Zeier J, Goll A, Yokoyama M, Karahara I, Schreiber L (1999) Structure and chemical composition of endodermal and rhizodermal/hypodermal walls of several species. Plant Cell Environ. 22:271-279. 